\title{
Modern Methods of Real Investments Financing
}

Larisa Ivanovna Yuzvovich

\begin{abstract}
Department of Insurance Ural Federal University named after the first President of Russia B.N. Yeltsin, Russia,
\end{abstract} Ekaterinburg, 620002, Ekaterinburg, 19 Mira, Str.

Elena Gennadevna Knyazeva

Department of Insurance Ural Federal University named after the first President of Russia B.N. Yeltsin, Russia, Ekaterinburg, 620002, Ekaterinburg, 19 Mira, Str.

Natalya Nikolaevna Mokeeva

Department of Insurance Ural Federal University named after the first President of Russia B.N. Yeltsin, Russia, Ekaterinburg, 620002, Ekaterinburg, 19 Mira, Str.

Natalya Yurevna Isakova

Department of Insurance Ural Federal University named after the first President of Russia B.N. Yeltsin, Russia, Ekaterinburg, 620002, Ekaterinburg, 19 Mira, Str.

Elena Anatolevna Smorodina

Department of State and Municipal Finances Ural State Economic University, Russia, Ekaterinburg, 620144, Ekaterinburg, 8 March,62 Street;

\section{Doi:10.5901/mjss.2015.v6n3s3p371}

\section{Abstract}

Financing of real investments is a basis of investment activity of the Russian enterprises in the conditions of investment process modernisation. The reasonable financing of investments solves a set of economic problems at macro, meso and micro levels, and creates favourable conditions for reforming and restructuring of economy. In modern conditions, the financial market mediates distribution of money funds between subjects of economic relations in the conditions of economy's market system. Financial market becomes the basic tool for attraction of funds and financings of investments into real sector of economy. Thus, the company can find investment resources in the financial market only on the conditions on which the majority of financial operations is currently carried out, and only from those sources which meet investment restrictions of the enterprise. It should be admitted that real investments are the element providing effective functioning of financial and credit system of national economy. Understanding the fact that real investments represent not only expense, how investments in the future, will help to arrange investment process more effectively. Use of real investments is carried out through realisation of investment projects directed for achievement of strategic targets of the state or the enterprise. In Russia the problem of real investments attraction was always a key issue both for the authority and business. During the economic shocks this problem becomes even more topical.

Keywords: financing, investment activity, financing sources, methods of real investments financing.

\section{Introduction}

\subsection{Introduce the Problem}

The conceptual basis of strategy of real investments financing presupposes selection of financing forms and methods, detection of financing sources of investments and their structure.

Despite of the multiversion researches carried out by scientists and experts in the sphere of research and possibility of attraction of new funds in real investments financing, applications of investment funds attraction ways which are economically more effective in order to provide financial marketability of a project, the most questions of this sphere were not answered by today.

In order to research a topical question about methods of real investments financing, and to base also strategy of 
real investment projects financing, the authors assume selection of financing methods, detection of real investments financing sources and their structure. While continuing to improve the methodology theory, the method of real investments financing serves as a way for attraction of investment funds in order to provide financial marketability of a project.

\subsection{Importance of the Problem}

The following point should be mentioned as a proof of topicality of this theme. Development of market relations, transformation of ownership structure and change of control system require development and application of new methods and approaches to financing of investments, including real investments.

Authors propose to consider economic essence of methodology as scientific research, before reasonable proving of necessity and suitability of modern methods of real investments financing.

\subsection{Relevant Scholarship}

Theoretical reasoning of investments' financing sources in modern conditions is presented in works of the following Russian scientists: Balabanov I.T., Veretennikova I.I., Vorontsovsky A.V., Zelenkov N.M., Limitovsky M. A., N.P. Makarkin, Malygin V. E., Melkunov Ya.S., Molyakov D.S., Pogorletsky A.I., Semenov V. P., Sergeev I.V., Sutyrin S.F., Smorodinskaya N.V., Stoyanov E. C., Teplova T.V., Temnik D.V., Khalevinskaya E., Yanovsky V.V.

Questions of investment management, administration of investments and cash flows in national economic system as a whole and between subjects of economic relations were discussed in works of a scientific elite: Blank I.A., Brighem J. F., S.J. Brown, J. K.Van Horn, Vahovich D.M., J. Dawnson, L.J. Gitman, Kreinin M. N, Lakhmetkin N.I., Ustenko O. L., Fabozzi F. D., Ehrhadt M. S., E.Helfert, U.Sharp and other.

\subsection{State Hypotheses and Their Correspondence to Research Design}

It should be noted that methodology questions cannot be limited only by philosophical or intrascientific scope, but should be discussed in a wide context. It means that is necessary to consider connection of science with manufacture at a certain stage of economic development, interaction of science with other forms of public consciousness, correlation of methodological aspect and subject of activity and many other economic factors.

Thus, it is possible to suggest the following structure of methodology in a wide scope:

1. Doctrine about features, principles, conditions, norms of activity.

2. Doctrine about subject, object, theme, forms, means, methods and results of activity.

3. Doctrine about stages and periods of activity: design, technological and final phases.

In the strict sense of the word, methodology is considered as a general theory about methods which was formed in connection with necessity of generalisation and development of such methods, means and ways which were discovered in philosophy, science and other forms of people's activity.

Lack of interest of researchers to methodology questions can be explained by the fact that there are still many unclear aspects in its essence, in questions of correlation of methodological and theoretical problems of science, correlation of methodology and philosophy. Initially problems of methodology were developed within the scope of philosophy on a base of dialogical, inductive, dialectic, phenomenological methods. Therefore the methodology is still closely connected with philosophy, especially with such sections as theory of cognition and dialectics.

Thus, logic scientific research is a method of modern logic which is applied for analysis of science language, discovering of logic structure of scientific theories and their components (definitions, classifications, concepts, rules, etc.), studying of possibilities and completeness of scientific knowledge formalization, etc.

\section{Method}

\subsection{Method of statistical monitoring}

The federal laws and legislative-statutory acts of the Russian Federation and its subjects concerning investments and investment activity, official statistical materials of the Federal service of state statistics; analytical materials of scientific and practical conferences; expert data of periodicals; reference materials and electronic information systems; analytical and financial reporting of business entities carrying out investment activity have made information and empirical base of 
the research. The information base is quite representative. Therefore there is a reliable basis for creation of coherent view of a complex technique of investment projects analysis.

\subsection{Method of analysis and measurement}

Statistical report on real investments financing, and namely structures of investments into basic capital, foreign investments according to types and countries, factors with negative influence on activity of organisations engaged in financial leasing from 2010 to 2013 was created by means of analytical analysis methods on the basis of generated database of the Russian Federation investment market condition.

The statistical report on quantitative information of financing sources allows to reveal trends for selection of optimal investments financing source, since the made decision influence not only viability of investment activity, but also distribution of final incomes, financial stability of enterprise providing stable economic development from the point of functionality and systemacy in the conditions of dynamical economic environment.

\subsection{Taxonomic method}

Studying of indicators of real investments financing in the period from 2010 to 2013 was carried out on a basis of taxonomic method: quantities of investments according to financing sources, including division of such sources to own and involved funds. Thus, the enterprise which uses only its own capital has the highest financial stability (its factor of autonomy make up one), but brakes its development rate (since it cannot provide necessary additional volume of assets at periods of favourable market condition) and does not use financial opportunities of acceleration of profit on the invested capital. Whereas, the enterprise that uses loan capital has higher financial potential of development and possibility of acceleration of financial profitability, though such an enterprise can face financial risk and threat of bankruptcy.

In the present scientific research we are going to consider the main types of these sources with reference to problems of real investments financing. Sources of real investments financing are funds which are used as investment resources. Generally they are subdivided to internal (own capital) and external (debt and loan capital).

Internal financing is provided at the expense of an enterprise planning to implement investment project. This assumes use of own means - first of all of net profit and depreciation charges. Thus, formation of means intended for implementation of investment project should have solely targeted character which can be reached particularly by allocation of independent budget for the investment project.

External financing provides use of external sources: funds of financial and credit institutes, non-financial companies, population, state, foreign investors, as well as additional investments of money resources from founders of the enterprise. External financing is carried out by mobilisation debt (shared financing) and loan (credit financing) means.

Let's consider correlation of methods and forms of investments financing (fig. 1) and analyse some of them more detailed.
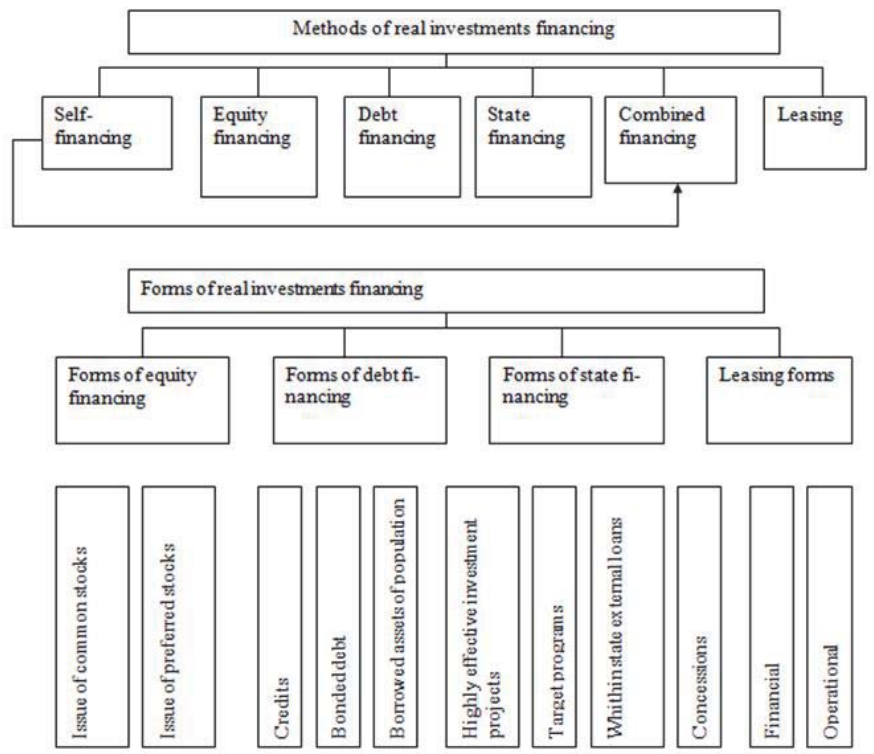

Figure 1. Correlation of methods and forms of real investment financing 
Currently the enterprise should make a choice from numerous directions of development and technical solution. Since investment process develops from a set of investment solutions on microeconomic level, the right choice is very important for each specific enterprise. This allows to consider creation of mechanism of investment process formation at the enterprise as the key problem of economic science and practice.

\subsection{Method of observational generalization and logical inference}

There are various opinions about structure of real investments financing methods in economic literature. The following methods are applied in practice: self-financing; equity financing; debt financing; state financing; combined financing; leasing.

Each applied method of financing has certain advantages and disadvantages. The choice of a method is carried out on the basis of comparison of various alternative plans and financing forms. For example, it is important to observe a proper balance between long-term debts and equity capital, since the higher share of debt funds, the higher the sum which should be paid in percents is. Applied financial scheme should:

- provide necessary volume of investments;

- promote optimisation of investments structure and tax payments;

- decrease capital outlays and risks of a project;

- set a balance between the volume of debt funds and the volume of gained profit.

\section{Results}

Self-financing consists in the fact that after exception of taxes and other obligatory payments to budget from profit, all other money savings remain at disposal of an enterprise (organisation). The expanded reproduction and solving of social problems of the enterprise can be provided at self-financing by use of own resources. Creation of self-financing system assumes increase of share of own resources (profit and depreciation charges) in financing of investment programs of the enterprises. Self-financing can be used only for realization of small investment projects. As a rule capital-intensive investment projects are financed not only from internal, but also from external resources.

Equity financing is one of the ways for attraction of own means for investment process of the Russian Federation residents. The authors assume that issue of securities, stocks, bonds, bills, etc. is one of the most widespread forms of investment projects financing.

Issue of stocks is preferable at financing of initial stages of large investment projects. The economic essence of stocks is a model of profit of economic relations subjects'. Certainly, conclusion of specific transaction does not require check a real resource of investor's funds (moreover, this can seriously damage investment projects in our country).

Equity financing provides shared financing of real investments. Shared financing of investment projects can be carried out in the following main forms:

- additional issue of stocks of the operating enterprise which is a joint-stock company by organizational and legal form, with a view of financial support of investment project realization;

- attraction of additional funds (investment contributions, fees, shares) of founders of the operating enterprise for investment project realization;

- creation of a new enterprise intended specially for realization of investment project.

Additional issue of stocks is used for realization of large real investments, investment programs of development, branch or regional diversification of investment activity. Application of this method mainly for financing of large real investments is explained by the fact that expenses connected with issue are covered only by considerable volumes of borrowed funds.

Attraction of investment resources in the equity financing can be carried out by additional issue of common and preference stocks. According to the Russian legislation, the par value of issued preferred stocks should be not more than $25 \%$ of the authorized capital of joint-stock company. It is considered that issue of preferred stocks as a form of equity financing is more expensive source of real investments financing compared to issue of common stocks, since dividend payment to shareholders is obligatory at preferred stocks. At the same time, common stocks, unlike preferred ones, provide the owners with more rights in participation in management including possibility to control the targeted use of funds for real investments financing.

The main advantages of share sales as a method of real investments financing are as follows:

- payments for the use of debt funds are not unconditional, but are carried out depending on financial result of a joint-stock company; 
- use of debt investment resources has large scales and is not limited to terms;

- $\quad$ issue of stocks allows to form necessary volume of funds at the beginning of investment project realization, as well as to delay payment of dividends until the period when project starts to bring income;

- stock owners can control the target use of funds allocated for investment project realization.

Financing sources of investments is currently one of the key problems in investment activity. The system of investments financing is formed by inherent unity of investment activity financing resources and financing methods. The investment activity depends much on the developed investment climate in a country, political and social situation. The structure of investments to basic capital according to financing resources from 2012 to 2013 (table 1), according to data from official site of the Federal service of state statistics is presented below.

Table 1 - Structure of investments into basic capital according to financing resources, in \% to a result

\begin{tabular}{|l|c|c|c|}
\hline Indications & 2012 & 2013 & Deviation $(+/-)$ \\
\hline Investments to the basic capital - total & 100 & 100 & - \\
\hline Including according to financing recourses: & & & \\
\hline Own funds & 44,5 & 46,1 & $+1,6$ \\
\hline Debt funds & 55,5 & 53,9 & $-1,6$ \\
\hline including: & & & \\
\hline bank credits & 8,4 & 9,3 & $+0,9$ \\
\hline including credits from foreign banks & 1,2 & 0,9 & $-0,3$ \\
\hline borrowed assets of other organizations & 6,1 & 6,2 & $+0,1$ \\
\hline budgetary funds (funds of consolidated budget) & 17,8 & 18,8 & $+1,0$ \\
\hline including: & & & \\
\hline federal budget & 9,6 & 9,8 & $+0,2$ \\
\hline budgets of territorial entity of the RF & 7,1 & 7,7 & $+0,6$ \\
\hline local budgets funds & 1,1 & 1,3 & $+0,2$ \\
\hline means of non-budgetary fund & 0,4 & 0,3 & $-0,1$ \\
\hline means of organisations and population for share building & 2,7 & 3,0 & $+0,3$ \\
\hline including means of population & 2,1 & 2,3 & $+0,2$ \\
\hline other & 20,1 & 16,3 & $-3,8$ \\
\hline
\end{tabular}

The basic forms of debt financing of real investments are credits of banks and target bonded debts. Credits of banks is one of the most effective forms of external financing of real investments, in the event that company cannot provide their realization by own means and issue of securities. Financial appeal of this form is explained first of all by the following factors:

- possibility to develop a flexible scheme of financing;

- no expenses connected with registration and distribution of securities;

- use of financial lever effect which allows to increase profitability of own capital depending on ratio of own and debt capital in a structure of invested means and cost of debt funds.

As a rule, credit resources are medium- and long-term. Term of attraction of investment credit is comparable to terms of investment project realization. Thus, the credit can provide a grace period, i.e. the grace period for repayment of the basic debt. This condition facilitates service of a credit, but increases its cost, since percentage payments are estimated from the outstanding amount of debt. As a rule, credits in the Russian practice are drawn up in a form of term loan with term of repayment from three to five years on the basis of drawing up of the corresponding credit agreement (contract). In some cases the bank can open a credit line for the borrower for this period.

Standard mortgage loans can be used for financing of real investments. The system of mortgage crediting provides a mechanism of accumulation and long-term crediting with low percent and long-period instalments of its payment.

In case of long and close cooperation between creditor bank and borrower for financing of real investments, the bank can open investment credit line for the borrower. The investment credit line is a legal registration of obligation of the creditor to the borrower for providing of credits (tranches) within a certain period, on an accrual basis of need of the borrower to finance specific capital expenses as a part of project within the agreed limit. Opening of a credit line has a number of advantages both for the borrower and for the creditor. Advantages for the borrower consist in reduction of overhead costs and loss of time connected with negotiating and conclusion of each specific credit agreement, as well as saving at percentage service of the credit sums exceeding current needs for financing of the investment project. Besides 
reduction of costs connected with registration and service of credit contracts, the creditor bank gets simplified tasks of refinancing (search of resources) of credit funds and lower risks of non-return of the credit as a sum of separate tranches which are less than credit sum by its single provision. At the same time, the creditor bank takes up the risks connected with change of economic activity in the market of loan capitals, since irrespective of type of these changes, the bank is obliged to carry out its obligations to the borrower and to provide it with loan according to the agreement on credit line.

As to borrowed resources of real investments financing, they are provided to the organisation on a loan basis for a certain term according to conditions of definite period, recurrency and serviceability.

Currently the share of attracted funds in financing of the basic capital of the Russian enterprises is rather big about $60 \%$. It could be assumed that the basic resources here are bank credits for financing of investment programs. The share of bank credits in financing of the basic capital has essentially increased (more than three times) within five years.

Crisis of liquidity of credit institutions is a consistent weakness of the Russian economy which puts it in deliberately low position in relation to other economically developed countries which have wide opportunities of fast and effective redistribution of the social capital in favour of the most developed sectors of economy. The Russian experience shows that crediting of enterprises and material production sphere is not included into a circle of interests of commercial and bank structures. High bank percent for credit do not allow many enterprises to use this source of investments; therefore its share in a total amount of investments is insignificant. The funds received from legal and natural persons on conditions of serviceability and recurrency on a loan basis, concern to group "loans". Issue of bonds by the business entity can serve as an example of such loan.

The long-term credit is not so wide spread, because of a high bank risk, backwardness of proper insurance system, and because of financial inconsistency of many enterprises.

Enterprises are still focused on own means in investment activity. In $201467 \%$ of enterprises used own funds for investment activity; $33 \%$ of enterprises used credit and loan funds.

Source of real investments financing can be the investment tax credit as a form of state support of investors. The investment tax credit is a specific form of alienation of potential tax revenues to the accounts of exchequer which is shown in the following:

- current tax obligations of the organisations decrease for a certain term;

- the sums of non-reimbursable taxes are transformed to additional source of capital investments financing;

- using of means is carried out on favourable conditions in comparison with conditions of receiving of a bank credit.

In this process the state acts as creditor, the borrower is a taxpayer, and current tax payments turn to the sum of the credit which the borrower returns to the creditor in the same rate, and also pays percent for using of money funds. Thus, real movement of funds from the creditor to the borrower does not happen, as it does at receiving of the bank credit. In modern conditions, investment support in a form of investment tax credit is especially topical for small enterprises with low level of investment in the basic capital.

The organisations which investment projects provide conformity to the following requirements have priority right for receiving of the investment tax credit:

- least period of return of received funds;

- greatest number of newly created workplaces in reliance on one rouble of provided investment tax credit;

- greatest amount of tax revenues in the budget of the territorial entity of the RF from project realization in reliance on one rouble of provided investment tax credit.

Theoretically the principle of a target orientation of the investment tax credit should support investment activity of enterprises which are carrying out capital investments.

Thereupon, adaptation of the mechanism of providing the investment tax credit as a way of the state support, to requirements of a modern economic situation would allow to encourage private investments into modernisation of own manufacture, realization of implementation or innovation activity by the enterprises etc. in order to implement innovative scenario of economy development for the period till 2020 which is a part of the concept of long-term social and economic development of the Russian Federation.

In practice of real investments financing, there are two kinds of leasing: operative (operational) and financial. Inherently difference between operative and financial leasing is a criterion of payback of ownership. In this respect, operative leasing is a leasing with incomplete payback, and financial leasing is a leasing with complete payback.

Operative leasing occurs at leasing of property for the period which is considerably smaller than amortisation term (as a rule, from two till five years). Financial leasing provides payment during the leasing payments contract period which covers full cost of amortisation of the equipment or its bigger part, additional costs and profit of lessor. Financial leasing 
requires big capital expenses and is carried out in cooperation with banks.

According to data of the Federal service of state statistics, authors have analysed business activity of enterprises which are carrying out activity in the sphere of financial leasing. The carried out micro research allowed to define several factors which negatively influence indicators of financial and economic activity. The most significant factors are competition with other organisations which are carrying out leasing activity (figure 1).

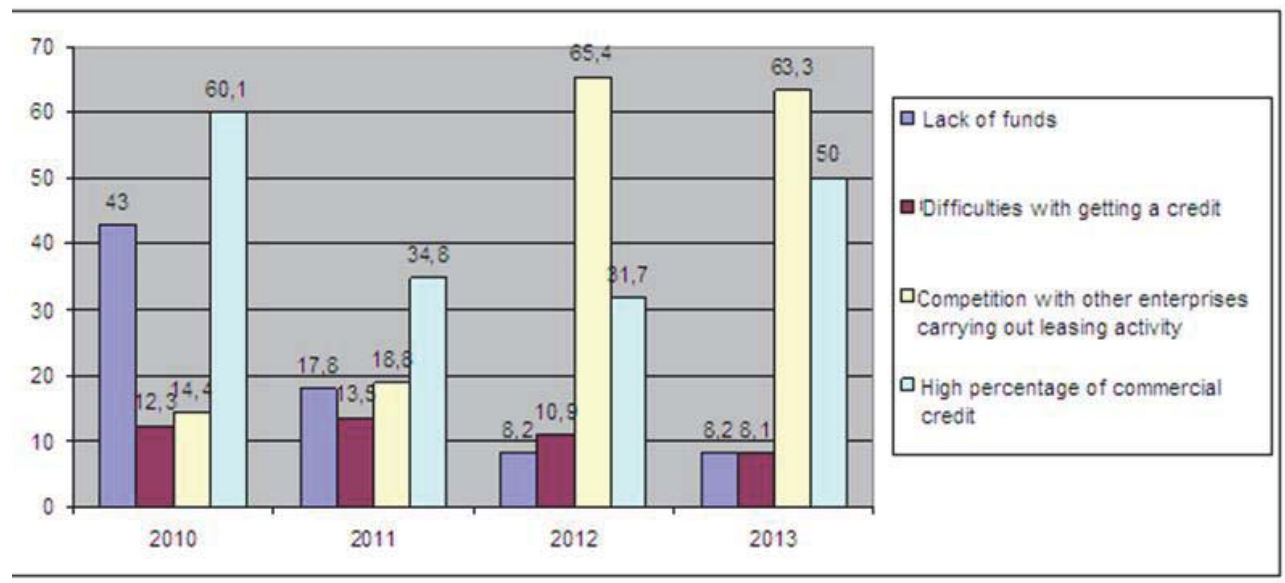

Figure 1. Factors which negatively influence activity of enterprises engaged in financial leasing (number of the answered enterprises, in \% of total)

About $60 \%$ of cost of concluded agreements is a cost of vehicles leasing, in leasing companies which are not subjects of small and medium-sized business. Leasing contracts for leasing of cars and equipment financial leasing contracts prevail in small enterprises among. Most actively financial leasing develops in Moscow, St.-Petersburg, Republic Tatarstan, Voronezh, Kaliningrad, Moscow and Tyumen oblasts. The share of leasing companies located in these subjects federal subjects of the Russian Federation makes up about $70 \%$ of total cost of concluded contracts.

The following kinds of crediting can be used in leasing as a source of real investments financing:

- bank credit, if the property which is provided under the leasing contract is purchased by lessor at the expense of bank credit;

- own means of the lessor, if the property which is provided under the leasing contract is purchased at the expense of own means of the lessor;

- bank credit and own means, if the contract subject is purchased using two sources;

- own means of the lessee in case of leaseback.

The authors suppose that leasing has signs of both industrial investment and credit. Its dual nature consists in the fact that on the one hand, it is a kind of capital investment, since it assumes investment of means in material property in order to get profit, and on the other hand, leasing has features of credit (it is provided on the conditions of definite period, recurrency and serviceability).

It is necessary to stress that foreign investments are a financing source for expanded renewal of capital assets.

The structure of foreign investments in Russia (table 2) shows that foreign investors are not ready to bear risk of arrangement of own manufacture in the Russian territory, but readily finance the Russian bank system. The reason could be the same as the reason why the Russian banks do not want to finance domestic investment projects with long-term payback.

According to the current legislation of the Russian Federation, foreign investors are provided with a full and unconditional legal protection in the country's territory. The item 7 of the Federal law «About foreign investments into the Russian Federation» includes a clause stating that «foreign investments into the Russian Federation are not subject to nationalisation contains and cannot be commandeered or confiscated». However further it is mentioned that such measures are taken «in exceptional cases provided by the legislation, when such measures are taken for the public benefit». Such legal duality provides the guarantees mentioned earlier with blurry meaning. 
Table 2 - Structure of foreign investments according to their types

\begin{tabular}{|l|c|c|c|c|}
\hline \multirow{2}{*}{ Indications } & \multicolumn{2}{|c|}{2012} & \multicolumn{2}{c|}{2013} \\
\cline { 2 - 5 } & Mln. US dollars & In \% from total & Mln. US dollars & In \% from total \\
\hline Foreign investments - total & 154570 & 100 & 170180 & 100 \\
\hline including: & & & & \\
\hline direct investments & 18666 & 12,1 & 26118 & 15,4 \\
\hline where: & & & & \\
\hline contributions to capital & 9248 & 6,0 & 9976 & 5,9 \\
\hline credits received from foreign co-owners of enterprises & 7671 & 5,0 & 14581 & 8,6 \\
\hline other direct investments & 1747 & 1,1 & 1561 & 0,9 \\
\hline portfolio investments & 1816 & 1,2 & 1092 & 0,6 \\
\hline where: & & & & \\
\hline stocks and shares & 1533 & 1,0 & 895 & 0,5 \\
\hline debt securities & 282 & 0,2 & 186 & 0,1 \\
\hline including bills & 254 & 0,2 & 132 & 0,1 \\
\hline other investments & 134088 & 86,7 & 142970 & 84,0 \\
\hline including: & & & & \\
\hline trade credits & 28049 & 18,1 & 27345 & 16,1 \\
\hline other credits & 97473 & 63,1 & 113950 & 66,9 \\
\hline $\begin{array}{l}\text { including } \\
\text { for term: }\end{array}$ & & & & \\
\hline to 180 days & 44543 & 28,8 & 21647 & 12,7 \\
\hline more than 180 days & 52930 & 34,3 & 92303 & 54,2 \\
\hline other & 8566 & 5,5 & 1675 & 1,0 \\
\hline
\end{tabular}

Statistical data from official information of the Federal service of the state statistics shows that Switzerland, Cyprus, the Great Britain and Luxembourg (figure 2) were the main investors in the Russian economy in 2013. The geography of investment cooperation is quite various. According to our estimations, there is interaction with investors from at least 25 countries of the world. Thus, the companies from Germany are registered in $40 \%$ of the country's regions, from the USA - in 36,7 \%, from Sweden - in $30 \%$, from China - in $20 \%$, from the Great Britain - in 16,7 \%, from France and Finland - in 13,3 \%. Canada, Belgium, Holland, Austria, Italy, Norway, Switzerland, Denmark, Czech Republic, Turkey have significant influence on economy of the Russian regions; less influence is exerted by Poland, Israel, South Korea, Cyprus, the Virgin Islands, Malaysia and Kazakhstan.

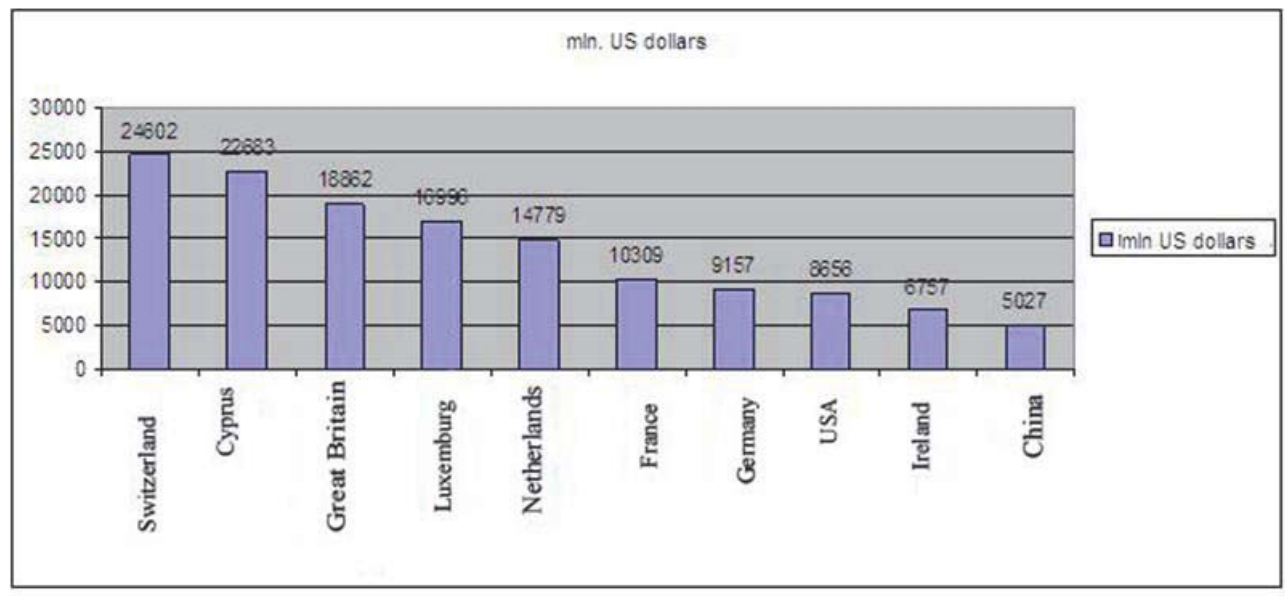

Figure 2. Inflow of foreign investments into economy of Russia in 2013 from to the basic investor-countries.

Both raised and borrowed funds can act as foreign investments. Direct investments of the foreign capital are the most important, because on the one hand they are closely connected with development of real sector of economy with 
implementation of modern technologies and methods of management and marketing, and on the other hand, the state does not bear any economic or political obligations on direct investments.

\section{Discussion}

Creation of a new enterprise intended specially for implementation of the investment project is one of the ways of target shared financing. It can be applied by private business owners establishing the enterprise for realisation of their investment projects and requiring attraction of partner capital; by large diversified companies which establish a new enterprise including on the basis of own structural divisions, for implementation of projects of production expansion, reconstruction and re-equipment of manufacture, reengineering of business processes, development of conceptually new production and new technologies; by enterprises are in a difficult financial condition which develop anti-recessionary investment projects for financial recovery, etc.

In these cases financial support of investment project is carried out by contributions of foreign cofounders in formation of the authorized capital of the new enterprise, allocation or establishment parent companies of the specialpurpose project companies - affiliated companies, creation of new enterprises by providing them a part of assets of the operating enterprises.

Venture capital financing is one of forms of real investments financing which presupposes creation of a new enterprise intended specially for implementation of investment project. It allows to raise funds for realization of initial stages of investment projects of innovative character (development and introduction of new types of production and technological processes) which are connected with high risks, but also with possibilities of significant increase of cost of the enterprises created for implementation of these projects. Venture capital financing presupposes attraction of means in the authorized capital of investors' enterprise which plan to sell their share in enterprise, when its cost increases during realization of the investment project. The persons who purchase the share of venture investor will get incomes from further functioning of the established enterprise. Venture capital investment differs from financing of the existing enterprises in this respect (by purchase of additional issue of stocks, shares, etc.) which shares can be purchased for the further resale.

Venture investors (physical persons and special-purpose investment companies) invest expecting to receive considerable profit. Together with experts they previously analyze both the investment project, and activity of the company which offers it, financial condition, credit history, quality of management, specifics of intellectual property. The special attention is drawn to the innovation level of the project which determines potential of fast growth of the company in many respects.

Venture investments are carried out in by purchasing of a part of venture enterprises assets which are not listed on stock exchanges yet, and by providing a loan, or in other forms. The venture enterprises are usually small enterprises which activity is connected with high risk of promotion of their products in the market. These are enterprises which develop new kinds of products or services which are unknown to the consumer yet, but have a big market potential. Development of the venture enterprise has several stages, thus each stage features various opportunities and financing sources. There are mechanisms of venture capital financing combining various kinds of capital: joint-stock, loan, enterprise. However, usually venture capital is an equity capital.

The practice shows that the venture enterprises can reach a high level of production profitability at development of new technologies and wide circulation of manufactured products. While the average rate of profitability of the state securities is $6 \%$, venture investors invest expecting to get the annual profitability of $20-25 \%$.

Thus, bearing in mind character of venture business, the venture capital is a risk capital and is compensated by high profitability of manufacture in which it is invested. The venture capital has a set of other features. One of such features is orientation of investors to increase of capital, instead of orientation to dividends for the invested capital. Since the venture enterprise starts to place shares in the share market in three-seven years after investment, the venture capital has a long term expectation of market realisation, and the amount of its increase is revealed only after entry of the enterprise the share market. Respectively, promoters' profit which is the basic form of profit from venture capital is sold by investors after the shares of the venture enterprise will start to be quoted in the share market.

One of the features of venture capital is distribution of risk among investors and initiators of a project. In order to reduce the risk, venture investors distribute the means among several projects, while one project can be financed by a number of investors. As a rule, venture investors strive to participate in management of business, in making strategic decisions, since they are directly interested in effective application of invested funds. Investors supervise financial condition of a company, actively promote development of its activity using own business contacts and experience in the spheres of management and finances. 
Attractiveness of capital investments in the venture enterprises is connected with the following: purchase of company's holding of shares with possibly high profitability; considerable increase of capital (from 15 to $80 \%$ annually); tax privileges.

Volumes of venture capital financing in grow dynamically in the industrial countries. The USA has the largest volume of venture investments in the world. The venture capital financing is essentially lower in countries of Western Europe and Asian-Pacific region. In Russia the venture capital is at the stage of formation: 20 venture funds manage financial assets of about 2 bln. dollars. Currently, the venture capital gets a key role in economy development. It is connected with the fact that venture enterprises helped to implement many development in the innovative spheres of the industry, to provide fast re-equipment and re-structuring of manufacture according to the modern scientific and technical basis.

Financing of real investments can be carried out by issue of target bonded loan. First of all, the company-emitter should have a steady financial condition, reasonable and efficient business plan of the investment project should bear the costs connected with issue and placing of bonds. As a rule, company uses services of professional competitors of securities market for completing a complex procedure of bonds issue. These competitors are investment companies and banks which services can cost 1-4 \% of issue par value for large volumes of bonded loan. Besides, when issuing bonds which together with stocks are issue securities, the emitters pay fee for a state registration of this issue.

Advantages of bonds are shown only in case of large loan volumes which are affordable only for big companies. This is caused not only by rather high issue expenses, but also by the fact that bond of small volumes of issue are low liquid. Meanwhile high liquidity of corporate bonds is one of characteristics which are the most attractive for investors. Functioning of the secondary market allows to define objective parameters of bond issues on which the emitter is focused while developing conditions of a bonded debt. The secondary market also allows to detect objective values of the rates of interest for attraction and placing of funds for emitters with various levels of credit risk.

Development of conditions of a target bonded debt presupposes fixing of the following key parameters:

- volume of loan which is defined by needs of the emitter for financing of real investments through attraction of funds for realization of the investment project, possibilities of the market to cover these needs under the price which provides required profitability of the investor, as well as by legislation requirements;

- term of loan which depends on the period of realization of the investment project, features of market conditions and legislative restrictions (in the Russian Federation the circulation term of corporate bonds cannot be less than year);

- par value defined by requirements of liquidity and the amount of expenses for service of a bonded debt;

- date and price of discharge of a bonded debt;

- $\quad$ form of bond issue (documented, undocumented, nominal, bearer);

- form of income payment (bond with fixed coupon, bonds with floating coupon, discount bonds or bonds with $t$ zero coupon);

- frequency and amount of coupon payments which are defined on the base of balancing of opposite directed factors: on the one hand, amount of expenses for service of a bonded loan, on the other hand - of profitability which is required for investors;

- country and currency of a loan. In relation to the national market, the bonds can be internal which are emitted by residents and as a rule are nominated in national currency, and external which are placed on foreign markets. External bonds are divided into the foreign bonds which as a rule are placed abroad in currency of the country of placing, and the Eurobonds placed outside of both country of borrower and country in which currency they are nominated;

- additional conditions of bonds issues intended for reduction of cost of loan's service and for compensation of risks and other parameters which can lower investment potential of bonds. The bonds with additional benefits for investors are bonds with the right of bond repurchase; bonds converted in stocks; secured bonds.

\section{Conclusion}

The main problem of the modern economic researches is development of theoretical and methodological bases of real investments financing which would promote stabilization of social and economic position in industry segments with prospect of further economic growth.

Promotion of investment process should pass in a real economy sector should be carried out according to clear investment programs and real investment projects. Strengthening of the regions' investment appeal will promote increase of investment activity of the enterprises in future. Increase of their credit rating can become a key tool of attraction of real 
investments. Development of a uniform system for assessment of the rating which would consider the principal factors of a region, openness and simplicity of calculation methods, will allow to unify the approach and to cause a proper response of regions to the received rating.

The above mentioned methods of real investments financing have a practical importance, but state and private partnership require a procedure for improvement of state financing of real investments with use of program and target method and modern tools and mechanisms.

\section{Acknowledgments}

Writing team would like to thank Metsger Aleksandr Albertovich, director general of ZAO "Upravlyaushaya kompaniya", Batrshin Albert Rafailovich, head of corporate relations department of LLC "UGMK-Holding" for providing a representative sample of analytical data on financing of real investments in scientific research.

\section{References}

Bulatov, A.S. (2011). Russia in the international movement of capital: comparative analysis / A.S. Bulatov//Economy questions. № 8. - P. 66-78.

Bulatov, A.S. (2004). Russia in the international investment process / A.S. Bulatov//Economy questions. № 1. - P. 74-84.

Igonina, L.L. (2012). Investments: tutorial/ L.L.Igonina; Under the editorship of V.A.Slepova. - M: Yurist, 480 p.

Ivanov, I.D. (2012). Russian investment abroad: benefits and risks / I.D.Ivanov//Bulletin of the state registration chamber. № 2. - P. 4-12.

Kreidich, T.V. (2010). Trends of transnationalization of world economy in the conditions of globalisation / T.V.Kreidich//MGTU Bulletin. T13. - №1. - P. 209-214.

Kuvshinova, O. (2012, January). Russian banks have credited foreign business of the Russian companies / O.Kuvshinova//Vedomosti. 13th - P.6.

Murphy, John (2012). The visual investor: how to detect trends. Publishing house: Alpina Publisher. $328 \mathrm{p}$.

Pakhomov, A.A. (2010). Influence of economic crisis on foreign investment expansion of the Russian companies / A.A. Pakhomov//Economic policy. № 5. - P.92-111.

Pakhomov, A.A. (2012). Export of direct investments from Russia: theory and practice essays/A.A. Pakhomov. - M: Publishing house of Institute of Gaydar. 368 p.

Smirnov, I.A. (2012, February, 1st.). Methodical instrument for assessment of investment prospects of projects I I.A.Smirnov//Technologies of TEK. pp.5-7.

Zhuravlyov, S. (2011). The biggest exporters and importers of capital in the modern history / S.Zhuravlyov//Ekspert. № 41. - pp. 24-25.

Zavadsky, M.V. (2011). China with money and ideas / M.V.Zavadsky//Ekspert. № 45. pp. 40-48.

Zele , R. (2012, June, 21st). WTO as an urge for investments: more than partnership for power resources. Special issue «Investments in Russia» / R.Zele//Vedomosti. pp.4-5. 
ISSN 2039-2117 (online) ISSN 2039-9340 (print)
Mediterranean Journal of Social Sciences MCSER Publishing, Rome-Italy
Vol 6 No $3 \mathrm{~S} 3$ May 2015 